\title{
Possible Therapeutic Effect of Crocin on Thioacetamide-Induced Liver Injury in Male Albino Rats
}

\author{
RAMEZ A.E. BARHOMA, M.D. \\ The Department of Physiology, Faculty of Medicine, Tanta University, Tanta, Egypt
}

\begin{abstract}
Background: Thioacetamide is an experimentally used hepatotoxic substance. Its hepatotoxicity is mainly due to increased cellular oxidative stress.

Aim: To evaluate the possible hepatoprotective effects of crocin on the damage induced by Thioacetamide in liver of male rats.

Methods: 50 male Wister rats were divided into 5 groups, 10 rats in each group; control group; given intraperitoneal injection of $1 \mathrm{ml}$ normal saline daily, thioacetamide group; received intraperitoneal injection of thioacetamide in a single dose $(300 \mathrm{mg} / \mathrm{kg})$, and three (Crocin + Thioacetamide) groups, received crocin in doses of $12.5,25$ and $50 \mathrm{mg} / \mathrm{kg}$ respectively after thioacetamide intoxication, as in group 2 . Then the animals were anaesthetized, blood samples were taken by cardiac puncture. Serum levels of aspartate amino transferase (AST), alanine amino transferase (ALT), and alkaline phosphatase (ALP) were determined. Moreover, the tissue levels of malondialdehyde (MDA), reduced glutathione (GSH) and glutathione peroxidase (GPx) were measured in liver tissue.

Results: Compared to control group, thioacetamide group, showed significant increase in serum levels of AST, ALT, ALP, and tissue levels of MDA, with significant decrease in tissue GSH and GPx. Crocin treatment significantly decreased serum levels of AST, ALT, ALP, and tissue levels of MDA and significantly increased tissue GSH and GPx, in a dose dependant manner.
\end{abstract}

Conclusion: Crocin treatment attenuated the liver injury caused by thioacetamide and its clinical application might be a new therapeutic approach in the liver diseases due to its anti-inflammatory and antioxidant properties.

Key Words: Crocin - Thioacetamide - Antioxidant-Reduced glutathione.

\section{Introduction}

THIOACETAMIDE (TAA) is a thiono-sulphurcontaining compound, that has been used in industry in the past [1]. TAA is hepatotoxic, frequently

Correspondence to: Dr. Ramez A.E. Barhoma, E-Mail: ramez.barhoma@Gmail.com used for experimental purposes; single dose administration leads to, dose dependent, acute liver injury characterized by centrilobular necrosis with subsequent regenerative response [2-4]. While, chronic exposure leads to hepatic cirrhosis and hepatocarcinoma [5].

TAA-induced hepatotoxic effects are manifested only after metabolic activation of TAA, by cytochrome P450, the TAA-intermediates will increase cellular oxidative stress $[6,7]$.

Crocin is a pharmacologically active compound of Crocus sativus L. (saffron) [8] . Saffron, is a spice that contain many chemical substances like carbohydrates, minerals, vitamins (especially thiamin and riboflavin) and pigments including crocin, carotene, anthocyanin, lycopene, and zigzantin $[9,10]$. Crocin has shown various pharmacological activities such as antioxidant, anticancer, radical scavenging, and genoprotective [11,12]. At pharmacological and high doses, crocin did not affect major organs of body by damage and no mortality was seen by crocin in mice [13] .

It remains unknown whether crocin can antagonize thioacetamide toxicity; thereby, we investigated its role towards thioacetamide-induced damages in hepatic tissues. The aim of the present study was to evaluate the possible hepatoprotective effects of crocin on the damage induced by thioacetamide in liver of male rats (using TAA-induced liver cirrhosis in the rat as a model system).

\section{Material and Methods}

All experimental procedures were performed from 1 st to 21 st July 2017, at the Physiology Department, Tanta University, while the histopathological analysis was carried out at the Pathology Department, Tanta University. 


\section{Animals:}

This study was conducted on 50 male Wister rats, weighing 200-230gm., obtained from the Experimental Animal House of Faculty of Science, Tanta University. All protocols were approved by the Ethical Committee of Tanta University. The rats were housed in plastic cages (5 rats per cage) at room temperature $\left(23 \pm 2^{\circ} \mathrm{C}\right)$, under controlled environmental conditions, $12 / 12 \mathrm{~h} \mathrm{light/dark} \mathrm{cycle}$ with free access to water and food.

Rats were divided into 5 groups, 10 rats per each group.

Group 1: Control group, given intraperitoneal injection of $1 \mathrm{ml}$ normal saline daily.

Group 2: Thioacetamide group, was intoxicated with a single dose of thioacetamide $(300 \mathrm{mg} / \mathrm{kg}$ intraperitoneally) freshly dissolved in saline [14].

Groups 3 to 5: (Crocin + Thioacetamide groups), were intoxicated with thioacetamide, in the same manner as in group 2, plus 12.5, 25 and $50 \mathrm{mg} / \mathrm{kg}$ crocin respectively, interaperitoneally once a day for 20 consecutive days [15] .

On the last day of experiments, all animals were anaesthetized with ketamine $(75 \mathrm{mg} / \mathrm{kg})$. Midline laparotomy was performed. Blood samples were taken by cardiac puncture; serum was separated by centrifugation (3000rpm for 10 minutes) and stored until assay. Also the livers were removed, specimens from lower centimeter long part of the right lobe were taken for histological evaluation, and estimation of oxidative stress in liver tissue.

\section{Chemicals:}

In this study, crocin (C44H64O24) and thioacetamide (C2H5NS) powders were purchased from Sigma-Aldrich (USA). They were dissolved and diluted in saline $(0.9 \%)$ for administration.

\section{Estimation of liver enzymes:}

Serum levels of aspartate amino transferase (AST), alanine amino transferase (ALT), alkaline phosphatase (ALP), were measured according to the methods described by Rej, [16] Ahmad and Hellebust, [17] and Tietz et al., [18] respectively.

Estimation of oxidative stress in liver tissue:

Liver samples were minced and homogenized $(10 \% \mathrm{w} / \mathrm{v})$ in ice-cold $0.1 \mathrm{M}$ sodium phosphate buffer ( $\mathrm{pH}$ 7.4). The homogenate was centrifuged at $4000 \mathrm{rpm}$ for $30 \mathrm{~min}$ at $4^{\circ} \mathrm{C}$. The resultant supernatant was used to measure malondialdehyde (MDA), reduced glutathione (GSH) and glutathione peroxidase (GPx) activity, using MDA, GSH and
GPx assay kits, following the manufacturer's instructions, according to the methods described by Janero [19], Akerboom and Sies [20], and Ursini et al., [21] respectively.

\section{Histopathological analysis:}

Liver specimens were fixed in $10 \%$ formalin at room temperature for $72 \mathrm{~h}$. Then washed under running water, dehydrated in ascending concentrations of ethanol and cleared in xylene. Finally, embedded in paraffin. Thin sections $(5 \mathrm{~m})$ vere cut using a microtome, subsequently stained with hematoxylin and eosin and evaluated by light microscopy.

\section{Statistical calculations:}

Statistical analyses of the collected data were performed by analysis of variance (ANOVA) to determine statistical significance between different groups using SPSS software package 23.0. Data was presented as mean \pm SD and $p<0.05$ was considered statistically significant.

\section{Results}

\section{Effect of crocin treatment on liver enzymes:}

TAA toxicity caused significant increase in the levels of liver enzymes; AST, ALT, and ALP, as compared with the control group. Treatment with crocin leads to significant reduction in the levels of AST, ALT and ALP, at the three doses, when compared with the TAA-treated group (Table 1) and Fig. (1).

\section{Effect of crocin treatment on liver oxidative stress:}

Measurement of MDA formation in the livers of TAA group showed a significant increase of the MDA formation when compared with the control group. It has been observed that treatment with crocin leads to significant reduction of MDA activity in a dose-dependent manner, when compared with the TAA group (Table 2) and Fig. (2).

The level of GSH and GPx activity were decreased significantly in TAA group as compared to the control group. Treatment with crocin showed significant elevation and restoration of GSH and GPx activity in the 3 groups of crocin as compared to the TAA-treated group (Table 2) and Fig. (2).

\section{Histopathological observations:}

The normal liver architecture of control group did not show any signs of inflammatory changes with well-preserved cytoplasm and nucleus. TAA causes disruption of tissue architecture in the form of centrilobular necrosis, vascular and sinusoidal congestion with inflammatory cell infiltration, 
which are indicative to hepatocellular injury. Crocin reduced liver injury caused by thioacetamide toxicity and largely suppressed sinusoidal congestion and inflammatory cell infiltration, improving liver architecture in a dose dependent manner as shown in Fig. (3).

Table (1): Levels of AST, ALT and ALP in all groups.

\begin{tabular}{llll}
\hline Group & AST (IU/l) & ALT (IU/l) & ALP (IU/l) \\
\hline Group I (control) & $37.25 \pm 1.23$ & $43.23 \pm 1.66$ & $133.88 \pm 10.00$ \\
Group II (TAA only) & $96.45 \pm 1.32^{\mathbf{a}}$ & $99.33 \pm 2.14 \mathbf{a}$ & $277.23 \pm 16.35 \mathbf{a}$ \\
Group III (crocin 12.5 + TAA) & $56.44 \pm 3.03^{\mathbf{b}}$ & $69.31 \pm 2.09 \mathbf{b}$ & $236.47 \pm 16.07 \mathbf{b}$ \\
Group IV (crocin 25 + TAA) & $42.62 \pm 1.26^{\mathbf{b}, \mathbf{c}}$ & $44.97 \pm 1.39 \mathbf{b}, \mathbf{c}$ & $208.60 \pm 6.53 \mathbf{b , c}$ \\
Group V (crocin 50 + TAA) & $40.26 \pm 1.26^{\mathbf{b}, \mathbf{c}, \mathbf{d}}$ & $43.61 \pm 1.36^{\mathbf{b}, \mathbf{c}}$ & $159.75 \pm 26.84 \mathbf{b , c , d}$ \\
\hline
\end{tabular}

Results represent mean $\pm \mathrm{SD}$.

$a: p<0.05$ vs group I.

$b: p<0.05$ vs group II.

$c: p<0.05$ vs group III.

$d: p<0.05$ vs group IV.

Table (2): Levels of MDA, GSH and GPx in all groups.

\begin{tabular}{lccc}
\hline Group & MDA (nmol/g tissue) & GSH (nmol/g tissue) & GPx (U/mg ptn) \\
\hline Group I (control) & $9.30 \pm 0.75$ & $0.65 \pm 0.02$ & $0.75 \pm 0.04$ \\
Group II (TAA only) & $36.58 \pm 4.03^{\mathbf{a}}$ & $0.15 \pm 0.02^{\mathbf{a}}$ & $0.35 \pm 0.04^{\mathbf{a}}$ \\
Group III (crocin 12.5 + TAA) & $18.94 \pm 1.07 \mathbf{b}$ & $0.34 \pm 0.04 \mathbf{b}$ & $0.53 \pm 0.03 \mathbf{b}$ \\
Group IV (crocin 25 + TAA) & $12.05 \pm 1.80^{\mathbf{b}, \mathbf{c}}$ & $0.54 \pm 0.05^{\mathbf{b}, \mathbf{c}}$ & $0.62 \pm 0.04 \mathbf{b , c}$ \\
Group V (crocin 50 + TAA) & $10.02 \pm 1.40^{\mathbf{b}, \mathbf{c}}$ & $0.57 \pm 0.05^{\mathbf{b}, \mathbf{c}}$ & $0.69 \pm 0.06 \mathbf{b , c , d}$ \\
\hline
\end{tabular}

Results represent mean $\pm \mathrm{SD}$.

$a: p<0.05$ vs group I.

$b: p<0.05$ vs group II
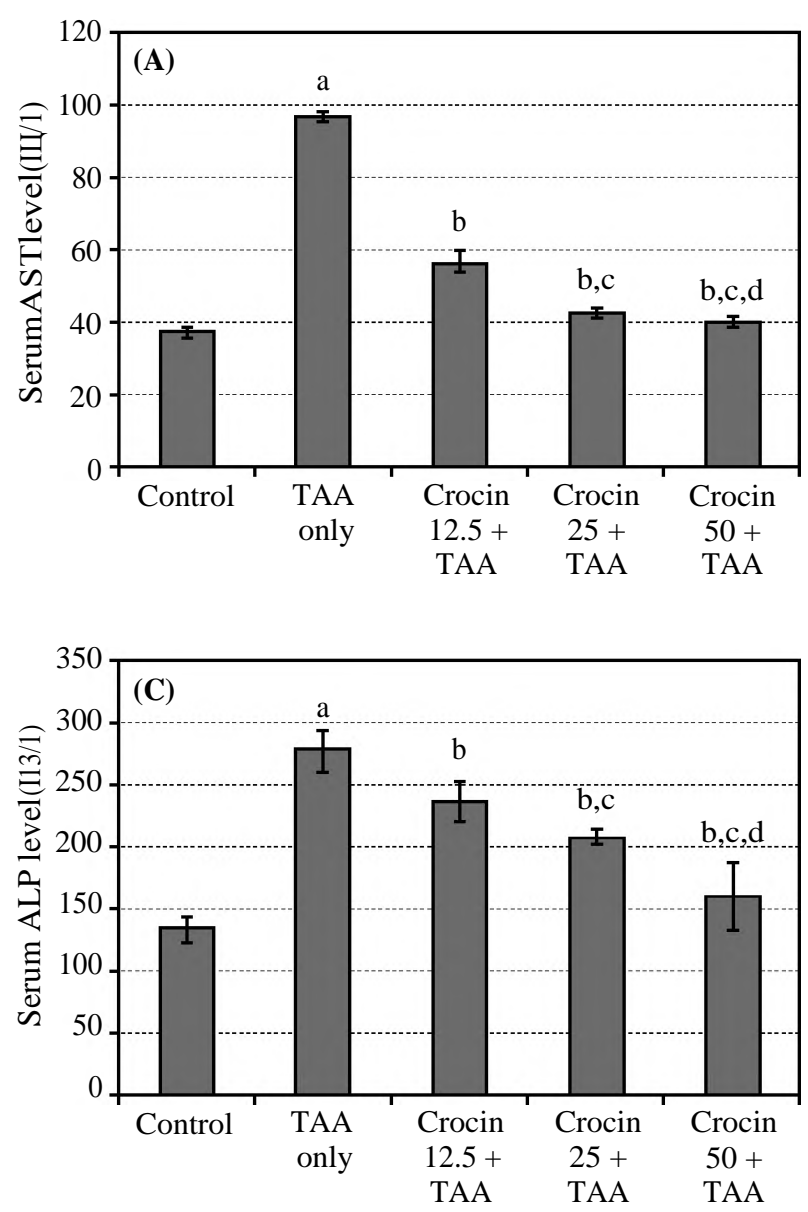

$c: p<0.05$ vs group III.

$d: p<0.05$ vs group IV.

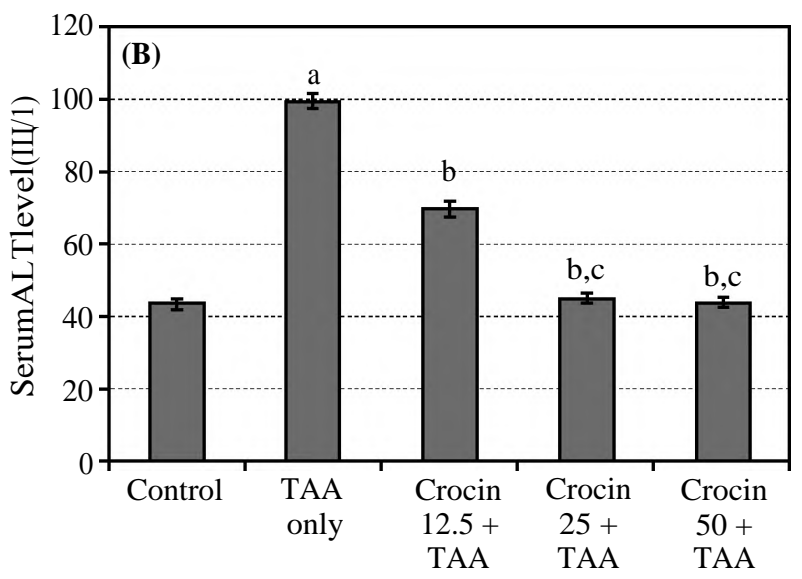

Fig. (1): (A) Serum AST level. (B) Serum ALT level. (C) Serum ALP level.

$a: p<0.05$ vs group I. $\quad$ c: $p<0.05$ vs group III. $b: p<0.05$ vs group II. $\quad$ d: $p<0.05$ vs group IV. 

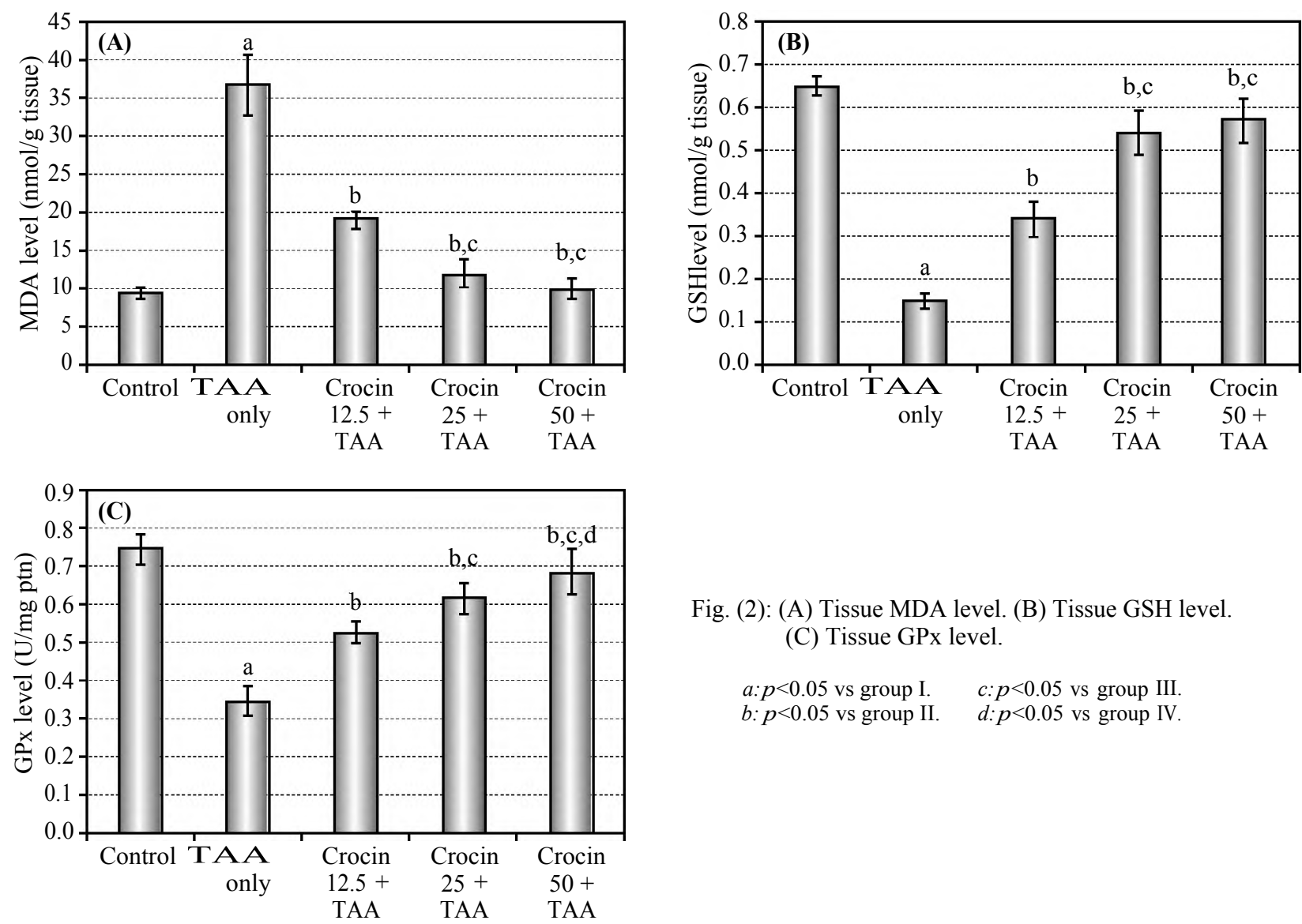

Fig. (2): (A) Tissue MDA level. (B) Tissue GSH level. (C) Tissue GPx level.
$a: p<0.05$ vs group I.
$c: p<0.05$ vs group III.

$b: p<0.05$ vs group II. $\quad d: p<0.05$ vs group IV.

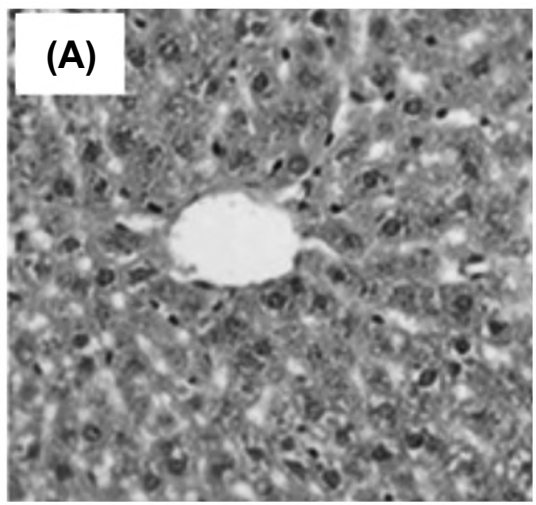

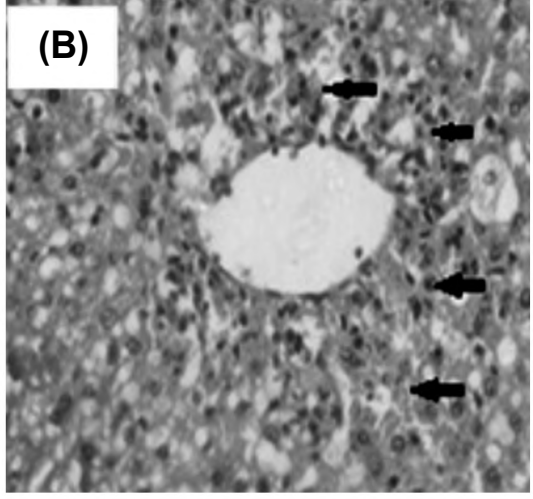

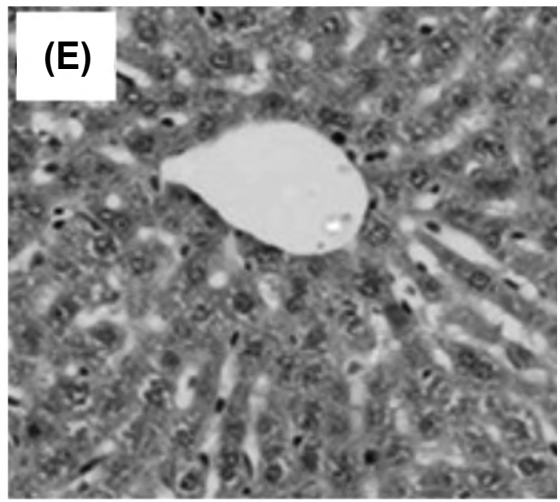

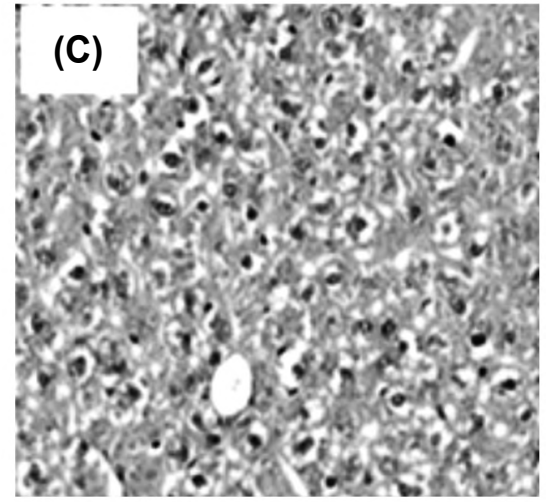

Fig. (3): Liver histopathology (X400). (A) Control group: Normal histology. (B) TAA group: Centrilobular necrosis, inflammatory cell infiltration, and sinusoidal congestion with red blood cells as shown by arrows. (C) Crocin $12.5 \mathrm{mg} / \mathrm{kg}+$ TAA group: Mild architectural damage, less sinusoidal congestion, and less inflammatory cell infiltration. (D) Crocin $25 \mathrm{mg} / \mathrm{kg}$ + TAA group: Negligible destruction of liver tissue. (E) Crocin $50 \mathrm{mg} / \mathrm{kg}+$ TAA group: Normalization of liver histology. 


\section{Discussion}

TAA is an effective hepatotoxicant and its toxic effects have been accredited to the toxic reactive metabolite thioacetamide-S-oxide obtained from TAA bioactivation [3] . It interferes with the RNA movement from the nucleus to the cytoplasm which may cause membrane injury. Also, It reduces the rate of oxygen consumption as well as the number of viable hepatocytes [22]. So, prolonged administration of TAA may result in liver cirrhosis and cancer development in rats and mice that made it to be considered as a hepatotoxicant model $[23,24]$

The data of the present study showed that treatment with crocin resulted in protection against TAA-induced liver toxicity by attenuating oxidative stress and inflammatory reactions.

Results obtained from analysis of hepatic enzymes indicated a significant rise in AST, ALT and ALP in TAA-treated group compared with control group. This increase in liver enzymes could be explained by the destructive changes that occurs in TAA-treated group, and appeared in histopathological studies in the form of centrilobular necrosis. These destructive changes may be attributed to the inflammatory reactions, as proved by inflammatory cell infiltration in liver sections, and oxidative stress with accumulation of free radicals, as shown by the significant increase in the MDA level together with significant decrease in the GSH and GPx levels in the TAA group compared to control group.

Previous studies have shown that TAA increased the activities of different marker enzymes of heptocellular injury, e.g. AST, ALT and ALP [22]. Also, there is an increased oxidative stress after TAA administration indicated by increased lipid peroxidase levels $[22,25]$.

Production of free radicals and oxidative stress was considered to be one of the most important reasons for liver cells' death [26].

The increased activity of enzymatic markers of liver function is a good indicative of liver cell impairment [27]. As the resulted damage of cell membranes would release the enzymes into the circulation [28], it seems that the increased serum levels of liver enzymes indicate cellular leakage and structural damage [27].

In the present study, crocin treatment exerted a hepatoprotective effect as reported by significant decrease in liver enzymes, possibly by scavenging reactive free radicals and reduction of oxidative stress as shown by significant decrease in MDA and significant increase in GSH and GPx levels compared to the TAA group, this was reflected on histopathological studies as restoration of normal histology of liver.

It seems that the antioxidant properties of crocin could protect the liver cells from the damage induced by oxidative stress $[29,30]$.

The results of the present study were in line with findings of El-Maraghy and colleagues who showed that crocin has a protective effect against biochemical changes resulting from the effect of high doses of iron in liver cells [31]. And in agreement with those of Mohajeri and colleagues who showed that treatment with crocin significantly reduced serum markers of liver functions [32]

\section{Conclusion:}

Crocin may have ameliorative effects against TAA-induced hepatotoxicity. But, further studies are required to elucidate the exact mechanism at molecular level, before its clinical application could be recommended.

\section{Acknowledgments:}

The authors would like to thank Dr. Eman ElSaed, the assistant professor of pathology for her help in the histopathological part of this study.

\section{References}

1- KUČERA O., LOTKOVÁ H., STAŇKOVÁ P., PODHOLA M., ROU SAR T., MEZERA V., et al.: Is rat liver affected by non-alcoholic steatosis more susceptible to the acute toxic effect of thioacetamide? Int. J. Exp. Pathol., 92 (4): 281-9, 2011.

2- CHEN T.M., SUBEQ Y.M., LEE R.P., CHIOU T.W. and HSU B.G.: Single dose intravenous thioacetamide administration as a model of acute liver damage in rats. Int. J. Exp. Pathol., 89: 223-31, 2008.

3- STANKOVÁ P., KUCERA O., LOTKOVÁ H., ROU SAR T., ENDLICHER R. and CERVINKOVÁ Z.: The toxic effect of thioacetamide on rat liver in vitro. Toxicol. Vitro, 24 (8): 2097-103, 2010.

4- WONG W.L., ABDULLA M.A., CHUA K.H., KUPPUSAMY U.R., TAN Y.S. and SABARATNAM V.: Hepatoprotective Effects of Panus giganteus (Berk.) Corner against Thioacetamide-(TAA-) Induced Liver Injury in Rats. Evidence-Based Complementary and Alternative Medicine, 170303. Doi: 10.1155/2012/170303, 2012.

5- NATARAJAN S.K., THOMAS S., RAMAMOORTHY P., BASIVIREDDY J., PULIMOOD A.B., Ramachandran A., et al.: Oxidative stress in the development of liver cirrhosis: A comparison of two different experimental models. Journal of Gastroenterology and Hepatology, 21: 947-57, 2006 
6- CHILAKAPATI J., KORRAPATI M.C., HILL R.A., WARBRITTON A., LATENDRESSE J.R. and MEHENDALE H.M.: Toxicokinetics and toxicity of thioacetamide sulfoxide: A metabolite of thioacetamide. Toxicology, 230: 105-16, 2007.

7- PALLOTTINI V., MARTINI C., BASSI A.M., ROMANO P., NANNI G. and TRENTALANCE A.: Rat HMGCoA reductase activation in thioacetamide-induced liver injury is related to an increased reactive oxygen species content. J. Hepatol., 44: 368-74, 2006.

8- RIOS J.L., RECIO M.C., GINER R.M. and MANEZ S. An update review of saffron and its active constituents. Phytother. Res., 10: 189-93, 1996.

9- ASSIMOPOULOU A.N., SINAKOS Z. and PAPAGEORGIOU V.P.: Radical scavenging activity of Crocus sativus L. extract and its bioactive constituents. Phytother. Res., 19: 9971000, 2005.

10-FERNÁNDEZ J.: Anticancer properties of saffron, Crocus sativus Linn. Adv. Phytomed., 2: 313-30, 2006.

11-HOSSEINZADEH H., ABOOTORABI A. and SADEGHNIA H.R.: Protective effect of Crocus sativus stigma extract and crocin (trans-crocin 4) on methyl methanesulfonate-induced DNA damage in mice organs. DNA Cell Biol., 27: 657-64, 2008.

12- HOSSEINZADEH H., SHAMSAIE F. and MEHRI S.: Antioxidant activity of aqueous and ethanolic extracts of Crocus sativusL.stigma and its bioactive constituent, Crocin and Safranal. Pharmacog Mag., 5: 419-24, 2009.

13- HOSSEINZADEH H., SHARIATY M.V., SAMENI A.K. and VAHABZADEH M.: Acute and sub-acute toxicity of crocin, a constituent of Crocus sativus L. (saffron), in mice and rats. Pharmacology online, 2: 943-51, 2010.

14- SHARMA P., BODHANKAR S.L. and THAKURDESAI P.A.: Protective effect of aqueous extract of Feronia elephantum correa leaves on thioacetamide induced liver necrosis in diabetic rats. Asian Pac. J. Trop. Biomed., 2 (9): 691-5. Doi: 10.1016/S2221-1691(12)60211-1, 2012.

15- SALAHSHOOR M.R., KHASHIADEH M., ROSHANKHAH S., KAKABARAEI S. and JALILI C.: Protective effect of crocin on liver toxicity induced by morphine. Res. Pharm. Sci., 11 (2): 120-9, 2016.

16- REJ R.: Measurement of aminotransferases: Part 1. Aspartate aminotransferase. Crit. Rev. Clin. Lab. Sci., 21: 99-186, 1984

17-AHMAD I. and HELLEBUST J.A.: A spectrophotometric procedure for measuring oxoglutarate and determining aminotransferase activities using nicotinamide adenine dinucleotide phosphate-linked glutamate dehydrogenase from algae. Anal. Biochem., 180: 99-104, 1989.

18- TIETZ N.W., RINKER A.D. and SHAW L.M.: IFCC methods for the measurement of catalytic concentration of enzymes Part 5. IFCC method for alkaline phosphatase (orthophosphoric-monoester phosphohydrolase, alkaline optimum, EC 3.1.3.1). J. Clin. Chem. Clin. Biochem., 21: $731-48,1983$.

19- JANERO D.R.: Malondialdehyde and thiobarbituric acidreactivity as diagnostic indices of lipid peroxidation and peroxidative tissue injury, Free Rad. Biol. Med., 9: 515 40, 1990.

20- AKERBOOM T.P. and SIES H.: Assay of glutathione, glutathione disulfide, and glutathione mixed disulfides in biological samples. Methods Enzymol., 77: 373-82, 1981.

21- URSINI F., MAIORINO M. and GREGOLIN C.: The selenoenzyme phospholipid hydroperoxide glutathione peroxidase. Biochim. Biophys. Acta., 839: 62-70, 1985.

22- ANBARASU C., RAJKAPOOR B., BHAT K.S., GIRIDHARAN J., AMUTHAN A.A. and SATISH K.: Protective effect of Pisonia aculeata on thioacetamide induced hepatotoxicity in rats. Asian Pac. J. Trop. Biomed., 2 (7): 5115,2012 .

23- AL-ATTAR A.M.: Attenuating effect of Ginkgo biloba leaves extract on liver fibrosis induced by thioacetamide in mice. J. Biomed. Biotechnol., 761450, 2012.

24- SAKURAI T., KUDO M., UMEMURA A., HE G., ELSHARKAWY A.M., SEKI E., et al.: p38a inhibits liver fibrogenesis and consequent hepatocarcinogenesis by curtailing accumulation of reactive oxygen species. Canc. Res., 73 (1): 215-24, 2013.

25- SEHRAWAT A. and SULTANA S.: Abrogation of thioacetamide-induced biochemical events of hepatic tumor promotion stage by tannic acid in Wistar rats. J. Environ. Pathol. Toxicol. Oncol., 26: 9-20, 2007.

26- CORDOVA C., SIQUEIRA I.R., NETTO C.A., YUNES R.A., VOLPATO A.M. and CECHINEL FILHO V.: Protective properties of butanolic extract of the Calendula officinalis L.against lipid peroxidation of rat liver microsomes and action as free radical scavenger. Redox. Rep., 7: 95-102, 2002.

27- WANG J.Q., LI J., ZOU Y.H., CHENG W.M., LU C., ZHANG L., et al.: Preventive effects of total flavonoids of Litsea coreana leve on hepatic steatosis in rats fed with high fat diet. J. Ethnopharmacol., 121: 54-60, 2009.

28- JALILI C., TABATABAEI H., KAKABERIEI S., ROSHANKHAH S. and SALAHSHOOR M.R.: Protective role of Crocin against nicotine-induced damages on male mice liver. Int. J. Prev. Med., 6: 92. Doi:10.4103/2008 7802.165203, 2015.

29- HE S.Y., TANG F.T., WEN N., XU G.L. and SHENG L.: Effect of crocin on experimental atherosclerosis in quails and its mechanisms. Life Sci., 77: 907-21, 2005.

30- XIANG M., ZHOU C.H., LIU J. and LI W.N.: Crocetin inhibits leukocyte adherence to vascular endothelial cells induced by AGEs. J. Ethnopharmacol., 107: 25-31, 2006.

31- EL-MARAGHY S.A. and EL-SAWALHI M.M.: Hepatoprotective potential of crocin and curcumin against iron overload-induced biochemical alterations in rat. Afr. J. Biochem. Res., 3: 215-21, 2009.

32- MOHAJERI D., DOUSTAR Y., REZAEI A. and MESGARI-ABBASI M.: Hepatoprotective effect of ethanolic extract of Crocus sativus L.(Saffron) stigma in comparison with silymarin against rifampin induced hepatotoxicity in rats. Zahedan J. Res. Med. Sci., 12: 53-9, 2010. 


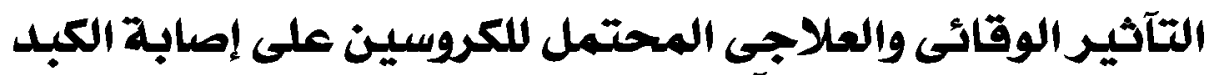

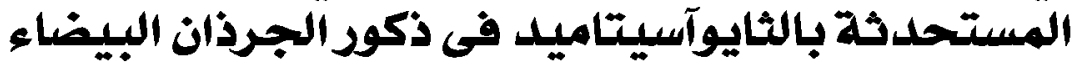

الهدف: تهدف هذه الدراسة إلى التحقق من التآثير الوقائى والعلاجى المحتمل اللكروسين على إصابة الكبد المستحدثة بالثايوآسيتاميد في ذكور الجرذان البيضاء.

طرق البحث:تم إجراء البحث على • 0 من ذكور الجرذان البيضاء مقسمة إلى ه مجموعات: مجموعة آ: مجموعة ضابطة، آعطيث محلول

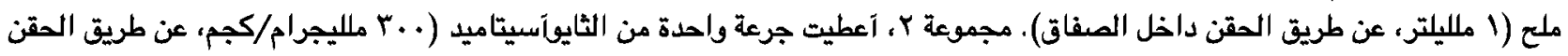

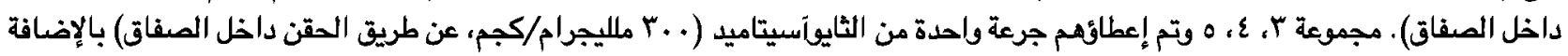

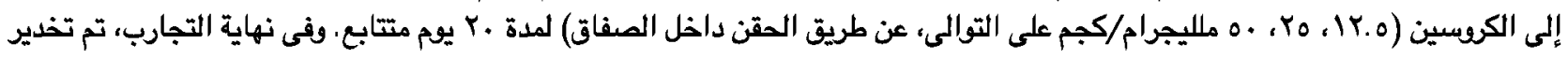

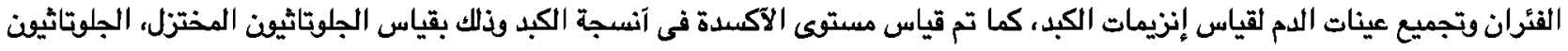

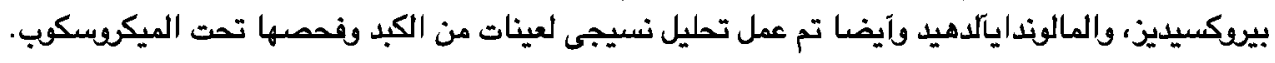

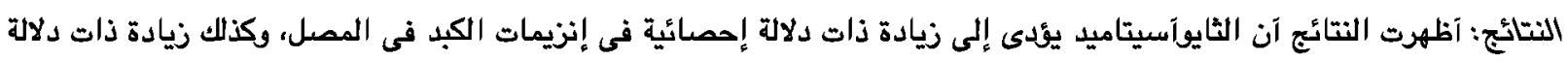

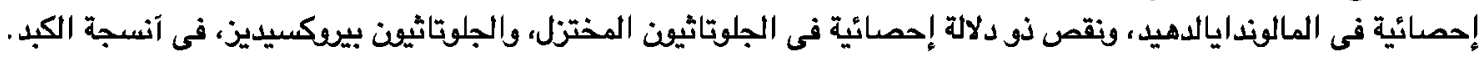

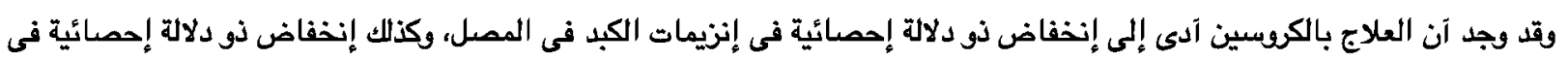

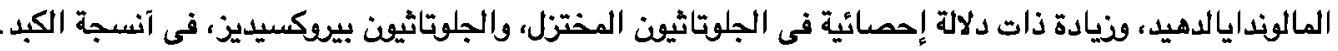

الخلاصة: العلاج بالكيروسين يؤدى إلى تحسين إصابة الكبد المستحدثة بالثايوأسيتاميد وذلك عن طريق تبيط الآكسدة والإستجابة التهابية 